\title{
Assessing Controls on the Displacement of Tracers in Gravel-Bed Rivers
}

\author{
Daniel Vázquez-Tarrío ${ }^{1,2, *(1)}$ and Ramon J. Batalla ${ }^{3,4,5}$ \\ INDUROT, University of Oviedo, Campus de Mieres, s/n 33600 Mieres, Spain \\ Department of Geology, University of Oviedo, c \Jesús Arias de Velasco, s/n 33005 Oviedo, Spain \\ Fluvial Dynamics Research Group (RIUS), University of Lleida, 25003 Lleida, Catalonia, Spain \\ Catalan Institute for Water Research (ICRA), 17241 Girona, Catalonia, Spain \\ 5 Facultad de Ciencias Forestales y Recursos Naturales, Universidad Austral de Chile, Valdivia 14101, Chile \\ * Correspondence: danielvazqueztarrio@gmail.com
}

Received: 8 July 2019; Accepted: 29 July 2019; Published: 31 July 2019

check for updates

\begin{abstract}
Particle travel length is one of the main dimensions of bedload and strongly influences river morpho-dynamics, particularly when exploring the interactions between sediment transport and channel morphology. This process has been traditionally studied by using tagged stones that allow tracking the movement experienced by individual grains during transport episodes. In this paper, we relate measured particle travel lengths to flow metrics and river channel parameters. First, we link the event-based bedload volumes to the active-layer dimensions, and the product between the average bedload rates and the duration of competent flows. We then hypothesize that travel length depends on channel width, surface grain-size, particle size, bed structure, flow strength, and duration of competent flow. The results from this approach are, subsequently, tested with a set of tracer observations from eight rivers that were available in the literature. The relationship between travel length and flow metrics was found to be statistically strong and has the potential to allow us to quantitatively assess the one-day dynamics of particles moving along streambeds. We also analyzed the influence of channel morphology and bed structure and identified morphological signatures for particle transport in gravel-bed rivers.
\end{abstract}

Keywords: gravel-bed rivers; bedload; particle travel length; tracers

\section{Introduction}

Bed material transport is fundamental to understanding river bed dynamics, since it controls and defines both channel morphology [1] and habitats [2]. Moreover, the quantitative characterization of the bed material load is central to many applied river issues, including channel engineering, characterization of ecosystem structure and functioning, assessment of impacts from gravel mining, hydropeaking and dams, risk management, and eco-hydraulics [3]. However, the assessment of the bed material load remains a complex task due to its unsteady and non-linear character [3-6] and its acute variability under natural conditions [7-10]. This fact is especially important in gravel-bed rivers, where bed-material configuration presents specific characteristics (e.g., particle protrusion and hiding, grain-size sorting, imbrication) that imply further technical and methodological sampling problems.

In coarse-bed rivers, the gravel and cobble components control the development of channel morphology, and this critical sediment fraction travels as bedload. In this regard, particle travel length is one main dimension of the sediment load. Thus, understanding the different controls on particle travel length is relevant for many scientific and applied issues including, among others, river habitat assessment, channel design, gravel augmentation, and river restoration. Hence, it is not surprising that the study of the dispersal lengths of fluvial gravels has been a longstanding focus of interest for fluvial 
geomorphologists and sedimentologists, who have traditionally approached the problem using the particle tracking method. This experimental strategy entails using tagged stones (painted, magnets, RFID) to track the movement of individual grains during floods [11-19]. Tracers offer the ability to capture spatial patterns in bedload transport, whereas other field methods are more spatially restricted, such as fixed bedload traps [20] or point Helley-Smith sampling [21].

Tracer research highlights how the average distances travelled by tagged particles scale as a linear or a power law to various flow metrics, including shear stress [22], peak and cumulative excess stream power [23-26], dimensionless impulse [27,28], and excess energy [17]. However, many authors have also outlined the huge scatter in the existing tracer data $[17,29]$, which suggests the important role played by controls other than flow discharge such as channel morphology [24,29-35], flow duration ([36,37], the discussion by Comitti [17]), bed configuration and particle arrangement [38-41], previous river bed history, and/or antecedent subthreshold flow [27,42-47].

The main objective of this paper is to examine how different variables (hydraulic, morphological, and textural) exert control on particle travel distances in gravel-bed rivers. This work follows the paper by Vázquez-Tarrío et al. [29] that presented a broad analysis of tracer data compiled from the scientific literature, with the objective of (i) identifying the different sources of scatter in tracer data and (ii) providing new insights on how bedload works in gravel-bed rivers. In the present paper, we aim to go further into tracer data analysis, while providing clues to improve the prediction of particle transport in gravel-bed rivers. The present analysis is based on a combination of the Eulerian and Lagrangian approaches to bedload motion [48], and represents a significant contribution to bedload studies. The dispersal length of bed material is an important parameter for a suite of river processes, but its full understanding remains elusive and has not been linked to flow metrics in a straightforward and clear manner [17,49].

\section{Materials and Methods}

\subsection{Rationale}

Particle transport length is one of the main dimensions of bulk bedload mass, and it could be expected that bedload volumes measured 'at-a-station' correlate to the mean distance travelled by stones $[19,50]$. Early flume experiments by Fernández-Luque et al. [51] and later by Wong et al. [19] and Parker [50] effectively suggested that bedload rates correlate to particle travel lengths. More recently, Schneider et al. [26] found that correlations between bedload volumes and the mean distances travelled by tracers exist in natural streams. This is the hypothesis we explore in the present paper.

The event-based bedload transport volumes $\left(Q_{S}\right)$ can be estimated from the dimensions of the active layer of the streambed and the mean travel distance of bed sediments [17,52-58].

$$
Q_{S}=L \cdot W_{a} \cdot h \cdot(1-p)
$$

where $L$ is the average distance travelled by the bedload (in $\mathrm{m}$ ), $W_{a}$ is the mean active channel width (in $\mathrm{m}$ ), which is the portion of the channel that is active in bedload terms during transport episodes, $h$ is the average depth of the active layer (in $\mathrm{m}$ ), and $p$ is the fractional porosity of the channel sediment. We can then re-arrange Equation (1) and express $L$ as the dependent variable to give

$$
L=Q_{S} \cdot\left[W_{a} \cdot h \cdot[1-p]\right]^{-1}
$$

At the same time, we can approach event-based bedload volumes from the average bedload rate of the transport event $\left(q_{s}\right)$, times the duration of the competent flow $(t$, in seconds).

$$
Q_{S}=q_{s} \cdot t
$$


Bedload rates have often been formulated as a power function of the ratio between the peak flow metrics and the critical value of the flow parameter for the incipient of motion [59-61]. Due to their longstanding use in tracer studies, we use the specific stream power $(\omega)$ as the flow parameter, but in its non-dimensional form [62].

$$
q_{s}=A \cdot\left(\frac{\omega^{*}}{\omega_{c}^{*}}\right)^{\mu}
$$

where $\omega^{*}$ is the dimensionless stream power (the subscript ' $c$ ' refers to the critical or threshold stream power for incipient bed sediment motion) estimated from the following expression.

$$
\omega^{*}=\frac{g \cdot S \cdot Q}{\left(1.65 \cdot g \cdot D_{84}\right)^{\frac{3}{2}}}
$$

where $g$ is gravity acceleration, $S$ is the bed slope, $Q$ is the water discharge, and $D_{84}$ is the 84 th percentile of the surface grain-size distribution. Somehow, Equation (5) normalizes the specific stream power by the submerged weight of surface sediment, which arrives at an expression equivalent to the Shields parameter, but is based on flow discharge.

Considering Equations (2)-(4), the following expression can be derived.

$$
L=A \cdot\left(\frac{\omega^{*}}{\omega_{c}^{*}}\right)^{\mu} \cdot t \cdot\left[W_{a} \cdot h \cdot[1-p]\right]^{-1}
$$

Equation (6) describes the average travel distance of the bulk bed material load. However, considering the case of a tracer sample deployed on the streambed, one would expect that differences in the size of the tracer population could cause differences in the observed transport distance. Consequently, the tracers' grain-size should be incorporated into the analysis. In this regard, Church and Hassan $[63,64]$ documented that tracer grain-size relative to the bed-surface plays a role in downstream transport distance, with travel distances decreasing strongly with particle sizes coarser than the median size of the streambed surface. They expressed the influence of tracer size through the following scaling relationship.

$$
\frac{L_{D_{i}}}{L_{D_{50}}}=a \cdot\left[1-\log _{10}\left[\frac{D_{i}}{D_{50}}\right]\right]^{b}
$$

where $L_{D i}$ is the transport distance of individual grains of diameter $D_{i}, L_{D 50}$ is the mean transport distance of the median grain-size $\left(D_{50}\right)$, and $a$ and $b$ are the empirical intercept and coefficient, respectively. Assuming that $L \sim L_{D 50}$, and combining Equations (6) and (7), the following expression for the mean travel distance of tracers $\left(L_{T}\right)$ can be derived.

$$
L_{T}=A \cdot a \cdot\left[1-\log _{10}\left[\frac{D_{i}}{D_{50}}\right]\right]^{b} \cdot\left(\frac{\omega^{*}}{\omega_{c}^{*}}\right)^{\mu} \cdot t \cdot\left[W_{a} \cdot h \cdot[1-p]\right]^{-1}
$$

In addition, we could also assume that the active channel width scales with the total channel width $\left(W_{T}\right)$.

$$
W_{a}=\gamma_{W} \cdot W_{T}
$$

where $\gamma_{W}$ is the fraction of the total channel width that is involved in the bedload. Similarly, it is reasonable to assume that active depth scales with the grain-size of the streambed's surface [65]. Then, the active depth can be related to the $D_{84}$, considering that the 84th percentile is an adequate descriptor of the overall roughness of the streambed-surface $[66,67]$.

$$
h=\gamma_{H} \cdot D_{84}
$$


where the multiplying parameter $\gamma_{H}$ characterizes the vertical extent of the active layer in terms of the surface grain-size. Incorporating Equations (9) and (10) into Equation (8), the following expression is reached.

$$
L_{T}=A \cdot a \cdot \gamma_{W} \cdot \gamma_{H} \cdot\left[1-\log _{10}\left[\frac{D_{i}}{D_{50}}\right]\right]^{b} \cdot\left(\frac{\omega^{*}}{\omega_{c}^{*}}\right)^{\mu} \cdot t \cdot\left[W_{T} \cdot D_{84} \cdot[1-p]\right]^{-1}
$$

which expresses the mean travel lengths of tracers in terms of simple and measurable hydraulic and channel-bed parameters.

Most previous analyses have assumed that the different parameters are independent. However, this is far from reality, especially in the case of the $\gamma_{W}$ and $\gamma_{H}$, which describes the vertical and horizontal extent of the active layer. It may be argued that these parameters are stage-dependent, so they may show some degree of co-linearity with the $\omega^{*} / \omega_{c}{ }^{*}$ ratio. Similarly, they could also be influenced by the time duration of the competent flow [37]. Furthermore, channel dimensions may exert influence as well. For example, narrow channels likely have a narrower active width. However, wider channels may exhibit large patches of immobile bed sediment and, consequently, a larger proportion of inactive bed-surface than narrow channels for equivalent discharge conditions, which partially buffers this effect. Similarly, major protruding elements in the streambed have been reported to control the thickness of the active layer, with coarser channels tending to show thicker active layers for equivalent hydraulic conditions $[65,68]$. In contrast, coarser streambeds may be more armored or paved, which prevents scour, and, hence, decreases the horizontal and vertical extent of the active layer. Moreover, bed state and grain structures can exert control on grain displacements and bed mobility and influence the $\gamma_{W}$ and $\gamma_{H}$ parameters, which characterize the vertical and horizontal extent of the active layer. The influence of the bed state on bed mobility could be individually specified for each streambed through the critical stream power for incipient motion $\left(\omega_{c}\right)$. With all this in mind, we postulate the following.

$$
\gamma_{W}, \gamma_{H}=f\left(\gamma_{H} \text { or } \gamma_{W}, D_{84}, \omega, \omega_{c}, t\right)
$$

Based on our knowledge, information on the exact shape of the functions relating $\gamma_{W}$ and $\gamma_{H}$ to other parameters is scarce $[26,54,65]$. In this paper, and, for the sake of simplicity, we assume that relationships between these parameters can be best fitted by power equations. We can then modify Equation (11) to the formula below.

$$
L_{T}=A^{\prime} \cdot\left[1-\log _{10}\left[\frac{D_{i}}{D_{50}}\right]\right]^{b} \cdot \omega_{c}^{*^{c}} \cdot\left(\frac{\omega^{*}}{\omega_{c}^{*}}\right)^{d} \cdot t^{e} \cdot W_{T}^{f} \cdot D_{84}^{l}
$$

where $b, c, d, e, f$, and $l$ are the model coefficients, and $A^{\prime}$ is the model intercept. The focus of the present paper discusses Equation (13) against available tracer data compiled from the literature.

\subsection{Data Set Compilation and Grouping}

In order to verify the hypotheses and to check the validity of the proposed approach for explaining gravel displacement, we compiled data from published studies in several gravel-bed rivers. The work is, thus, based on a compilation of tracer studies carried out in the framework of previous research [29]. From the original data base (see Table 1 in Vázquez-Tarrío et al. [29]), we selected only those studies that provided information about the variables involved in Equation (13). Moreover, in order to avoid technical biases, we focused on tracer surveys where the particle recovery ratio exceeded $75 \%$ (see Table 1 for more details). Data were derived from tracer experiments that used magnetically and PIT tagged stones, and covered a wide range of channel morphologies and bed textures (some surveys in which the behavior of the frontrunners was not adequately considered were discarded). Altogether, the data set comprised 42 transport episodes in eight gravel-bed river reaches, for which we compiled the following information (Table 1): (a) channel width, channel slope, channel morphology, and grain-size, 
(b) tracing method, recovery ratio, mean and maximum travel distances, percentage of mobile tracers, and (c) critical discharge, flow magnitude, and duration of the transport episodes. Data were divided according to channel morphology (riffle-pool, step-pool, and plane-bed channels), as per Montgomery and Buffington [69]. An additional category (multi-thread channels) was specified for the wandering River Bouinanc. In addition, data were also grouped according to the experimental condition, as constrained and unconstrained-tracer measures [29]. Data from the first displacements after tracer seeding were considered 'unconstrained-tracer' data. Data from East Creek [70] were also included in this group, since buried tracers were dug during recovery, which may potentially have disturbed the bed. "Constrained" measures encompass the data from second and subsequent displacements after tracer seeding. 
Table 1. Sources of data and information for the tracer experiments compiled for this study.

\begin{tabular}{|c|c|c|c|c|c|c|c|c|c|c|c|c|c|}
\hline Data Set & $W(\mathbf{m})$ & $s$ & $\begin{array}{c}D_{50} \\
(\mathrm{~mm})\end{array}$ & $L(\mathrm{~m})$ & Measuring Procedure & Observations & $\begin{array}{l}\text { Recovery } \\
(\%)\end{array}$ & $Q\left(\mathrm{~m}^{3} / \mathrm{s}\right)$ & $\begin{array}{c}Q_{c}\left(\mathrm{~m}^{3} / \mathrm{s}\right) \\
\text { [Estimation } \\
\text { Method] }\end{array}$ & Seeding Procedure & $\begin{array}{c}\text { Survey } \\
\text { Duration }\end{array}$ & Stream Type & Source \\
\hline Lainbach & 10.0 & 0.020 & 120 & $15-451$ & No information & $\begin{array}{c}\text { Mean distances } \\
\text { estimated for all } \\
\text { tracers and for } \\
\text { moving tracers } \\
\text { only } \\
\end{array}$ & $17-100$ & $3.2-165.0$ & $\begin{array}{c}3 \\
\text { [First tracer } \\
\text { movements] }\end{array}$ & $\begin{array}{l}\text { Tracers seeded on } \\
\text { pools, steps, bars, } \\
\text { and the toss side of } \\
\text { large boulders }\end{array}$ & 4 years & Step-pool & $\begin{array}{c}\text { [71]: } \\
\text { Gintz et al. } \\
\text { (1996) }\end{array}$ \\
\hline Spruce creek & 6.0 & 0.120 & 86 & $163.8-513.9$ & $\begin{array}{l}\text { Straight line distance } \\
\text { between the initial } \\
\text { location and the point } \\
\text { of the final deposition }\end{array}$ & $\begin{array}{l}\text { Mean distances } \\
\text { estimated for } \\
\text { moving } \\
\text { tracers only }\end{array}$ & $83-92$ & $1.2-2.0$ & $\begin{array}{c}1 \\
\text { [Discharge above } \\
25 \% \text { of clasts are } \\
\text { mobile] }\end{array}$ & $\begin{array}{l}\text { Tracers seeded } \\
\text { along cross sections } \\
\text { on the channel bed }\end{array}$ & 3.5 years & Step-pool & $\begin{array}{c}\text { [24]: } \\
\text { Lamarre and } \\
\text { Roy (2008) }\end{array}$ \\
\hline $\begin{array}{l}\text { Halfmoon } \\
\text { Creek }\end{array}$ & 2.2 & 0.010 & 57 & $10.0-144.8$ & $\begin{array}{l}\text { Distances along and } \\
\text { away from the } \\
\text { channel centerline }\end{array}$ & $\begin{array}{c}\text { Mean distances } \\
\text { estimated for all } \\
\text { tracers and for } \\
\text { moving } \\
\text { tracers only } \\
\end{array}$ & 93-98 & $5.6-14.5$ & $\begin{array}{c}3.5 \\
\text { [Estimate based } \\
\text { on critical shields } \\
\text { stress] }\end{array}$ & $\begin{array}{l}\text { A grid of } 893 \text { tracers } \\
\text { in rows across the } \\
\text { channel with } 0.5 \mathrm{~m} \\
\text { between each tracer } \\
\text { and each row }\end{array}$ & 4 years & Riffle-pool & $\begin{array}{c}\text { [72]: } \\
\text { Bradley and } \\
\text { Tucker (2012) }\end{array}$ \\
\hline $\begin{array}{l}\text { Bouinenc } \\
\text { river }\end{array}$ & 24.0 & 0.020 & 20 & $299.0-775.0$ & $\begin{array}{l}\text { Distances measured } \\
\text { along the axis of the } \\
\text { main low } \\
\text { flow channel }\end{array}$ & $\begin{array}{c}\text { Mean distances } \\
\text { estimated for all } \\
\text { tracers and for } \\
\text { moving } \\
\text { tracers only }\end{array}$ & $65-88$ & $33.4-41.1$ & $\begin{array}{c}2.5 \\
\text { [Estimate based } \\
\text { on critical shields } \\
\text { stress] }\end{array}$ & $\begin{array}{l}\text { Tracers seeded } \\
\text { along transverse } \\
\text { lines crossing } \\
\text { several } \\
\text { morphological units }\end{array}$ & 3 years & $\begin{array}{l}\text { Multithread } \\
\text { channel }\end{array}$ & $\begin{array}{c}\text { [73]: } \\
\text { Liebault et al. } \\
\text { (2012) }\end{array}$ \\
\hline $\begin{array}{c}\text { Strimm } \\
\text { Creek }\end{array}$ & $3.5-4.0$ & $0.080-0.150$ & $62-76$ & $0.2-185.0$ & $\begin{array}{l}\text { Distances measured } \\
\text { along the thalweg }\end{array}$ & $\begin{array}{l}\text { Mean distances } \\
\text { estimated for } \\
\text { moving } \\
\text { tracers only }\end{array}$ & 54-100 & $0.32-1.81$ & $\begin{array}{c}0.3-0.4 \\
\text { [Discharges able } \\
\text { to mobilize clasts } \\
\text { from all size } \\
\text { classes] }\end{array}$ & $\begin{array}{l}\text { Tracers seeded } \\
\text { along transverse ribs } \\
\text { on the streambed }\end{array}$ & 4 years & $\begin{array}{l}\text { Step-pool/Plane- } \\
\text { bed/Cascade }\end{array}$ & $\begin{array}{l}\text { [74]: } \\
\text { Dell'Agnese et } \\
\text { al. (2015) }\end{array}$ \\
\hline East Creek & $2.3-2.8$ & $0.018-0.020$ & $49-55$ & $0.3-35.7$ & $\begin{array}{l}\text { Distances measured } \\
\text { along the thalweg }\end{array}$ & $\begin{array}{l}\text { Mean distances } \\
\text { estimated for } \\
\text { moving } \\
\text { tracers only }\end{array}$ & $77-88$ & $0.9-4.7$ & $\begin{array}{c}0.5 \\
\text { [Discharge at } \\
\text { which } ; \text { mobility is } \\
\text { initiated for the } \\
\text { median grain size] }\end{array}$ & $\begin{array}{l}\text { Tracers seeded on } \\
\text { the surface in rows } \\
\text { spanning the entire } \\
\text { width of the channel }\end{array}$ & 8 years & $\begin{array}{l}\text { Riffle-pool/ } \\
\text { Plane-bed }\end{array}$ & $\begin{array}{c}\text { [70]: } \\
\text { Papangelakis } \\
\text { and Hassan } \\
(2016)\end{array}$ \\
\hline
\end{tabular}

W: Channel width. S: Channel slope. $D_{50}$ : Median size of the surface grain-size distribution. L: Mean travel length. Q: Event discharge. $Q_{c}$ : Threshold discharge for incipient sediment motion. 


\subsection{Data Analysis}

To test whether Equation (13) fits the tracer data, we used ordinary multiple regression in a linearized form and stepwise procedures, after log transforming all the variables included in the equation (back-transformation bias was corrected following Miller's directions [75]). In addition, the Variance Inflation Factor (VIF) was computed to assess how much the variance of $R^{2}$ was inflated due to collinearity between the predictor variables. As a rule of thumb, when a regression model incorporates several explanatory variables, the value of VIF is acceptable if it is less than 10 [76]. Lastly, and with the aim of assessing the relative importance of each one of the independent variables, we used the method proposed by Lindeman et al. [77], which is often recommended for assigning shares of the relative weight of predictors to $R^{2}$, while also accounting for the sequence of predictors appears in the model. Moreover, previous tracer works have shown significant correlations between mean tracer travel distance and excess stream power [17], accumulated stream power [25,26], and dimensionless impulse [28]. With the aim of assessing whether Equation (13) improves upon previous approaches, we compared the performance of Equation (13) to two regression models applied to the same data (Table 1).

$$
\begin{gathered}
L_{T}=A^{\prime} \cdot\left(\omega-\omega_{c}\right)^{d} \\
L_{T}=A^{\prime} \cdot\left[\left[\omega-\omega_{c}\right] \cdot t\right]^{d}
\end{gathered}
$$

Critical stream power $\left(\omega_{c}\right)$ was estimated from the value of threshold discharge $\left(Q_{c}\right)$ provided by the different papers (Table 1). The comparison between the three regression models was based on the percentage of explained variance, evaluated for each regression model through $R^{2}$. Subsequently, and in order to assess the robustness of each regression model, we used Jacknife resampling methods $[78,79]$. For this, we sequentially extracted one data point from the data set, fitted the three regression models with the remaining data, and estimated the particle travel length for the extracted data with each regression model. Then, we defined two additional scores: (i) the average ratio $(r)$ between regression model estimates and field measured transport distances, in order to quantify the accuracy of each regression model, and (ii) the number of data plots in which $r$ falls between 0.5 and 2 , as a way to measure their precision.

Previous research has highlighted the importance of channel morphology and dominant macro-bedforms on particle transport in gravel-bed rivers [17,29,30,32]. To further assess this, we explored differences in how the regression model fitted to tracer data, according to channel morphology. We also defined a new parameter called the 'Energy Expenditure Index' (EEI), as a way to quantify the amount of energy needed to displace tracers per unit length (i.e., $1 \mathrm{~m}$ ).

$$
E E I=\frac{\left(\omega-\omega_{c}\right) \cdot t}{L}
$$

where $\omega$ is the specific stream power and $\omega_{c}$ is the critical value of $\omega$ for incipient sediment motion. We explored differences in the values of EEI according to channel morphology.

\section{Results}

\subsection{Regression Model}

The multiple regression analysis shows a highly statistically significant relationship between the mean travel distance and the independent variables included in Equation $(13)\left(R^{2}=0.87, p\right.$-value $\left.<0.05\right)$, and confirms that the proposed equation reproduces the compiled data with a high degree of adequacy. All of the variables are significant in explaining mean travel lengths at a $90 \%$ confidence level ( $p$-values $<0.1$ ), and they are all positively correlated with mean travel lengths (Table 2$)$. The fitted model coefficients are shown in Table 2. Values of VIF are high in the case of width and tracer size, but all perform below 10, which indicate that multicollinearity can be dismissed. 
Table 2. Results of multiple regressions using stepwise procedures based on Equation (13) (see text for details).

\begin{tabular}{cccccc}
\hline Variable & Coefficient & Standard Error & $\boldsymbol{t}$ & $\boldsymbol{p}$-value & VIF $^{\mathbf{1}}$ \\
\hline Intercept & 1170.146 & 2.686 & 3.47 & $0.001^{++}$ & \\
$1-\log _{10}\left(D_{i} / D_{50}\right)$ & 4.859 & 1.516 & 3.204 & $0.003^{++}$ & 4.574 \\
$D_{84}$ & 3.239 & 0.455 & 7.12 & $2.68 \times 10^{-8++}$ & 2.431 \\
Width & 3.878 & 0.51 & 7.608 & $6.38 \times 10^{-9++}$ & 6.239 \\
$\omega^{*} / \omega_{c}^{*}$ & 1.931 & 0.278 & 6.945 & $4.49 \times 10^{-8++}$ & 1.908 \\
Flow duration & 0.167 & 0.084 & 1.991 & $0.054^{+}$ & 1.908 \\
$\omega_{c}^{*}$ & 2.742 & 0.554 & 4.952 & $1.85 \times 10^{-5++}$ & 4.002 \\
\hline
\end{tabular}

Residual standard error: 0.854 on 35 degrees of freedom. Multiple $R^{2}=0.87$. Adjusted $R^{2}=0.85$. F-statistic: 38.86 on 6 and 35 degrees of freedom. $p$-value $=4.64 \times 10^{-4} .{ }^{1}$ Variance Inflation Factor (see Section 2.3 in the text for details). $D_{i} / D_{50}$ : Ratio between tracer size $\left(D_{i}\right)$ and the median size of surface sediment $\left(D_{50}\right)$. $D_{84}:$ : 4 th percentile of the surface grain-size distribution. $\omega^{*}$ : Dimensionless specific stream power. $\omega_{c}^{*}$ : Threshold value of $\omega^{*}$ for incipient sediment motion. ${ }^{++}: p$-value statistically significant at a $95 \%$ confidence level. ${ }^{+}: p$-value statistically significant at a $90 \%$ confidence level.

Moreover, the analysis of the relative weight of each predictor in explaining data scatter indicates that almost $40 \%$ of $R^{2}$ is explained by channel width $\left(W_{T}\right)$ (Figure 1 ). The $\omega / \omega_{c}$ ratio and flow duration explain, together, around $25 \%$ of $R^{2}$. $D_{84}$ and critical stream power account for $~ 20 \%$ of the explained variance. Lastly, the tracer size relative to the bed sediment is responsible for $16 \%$ of the explained variance.

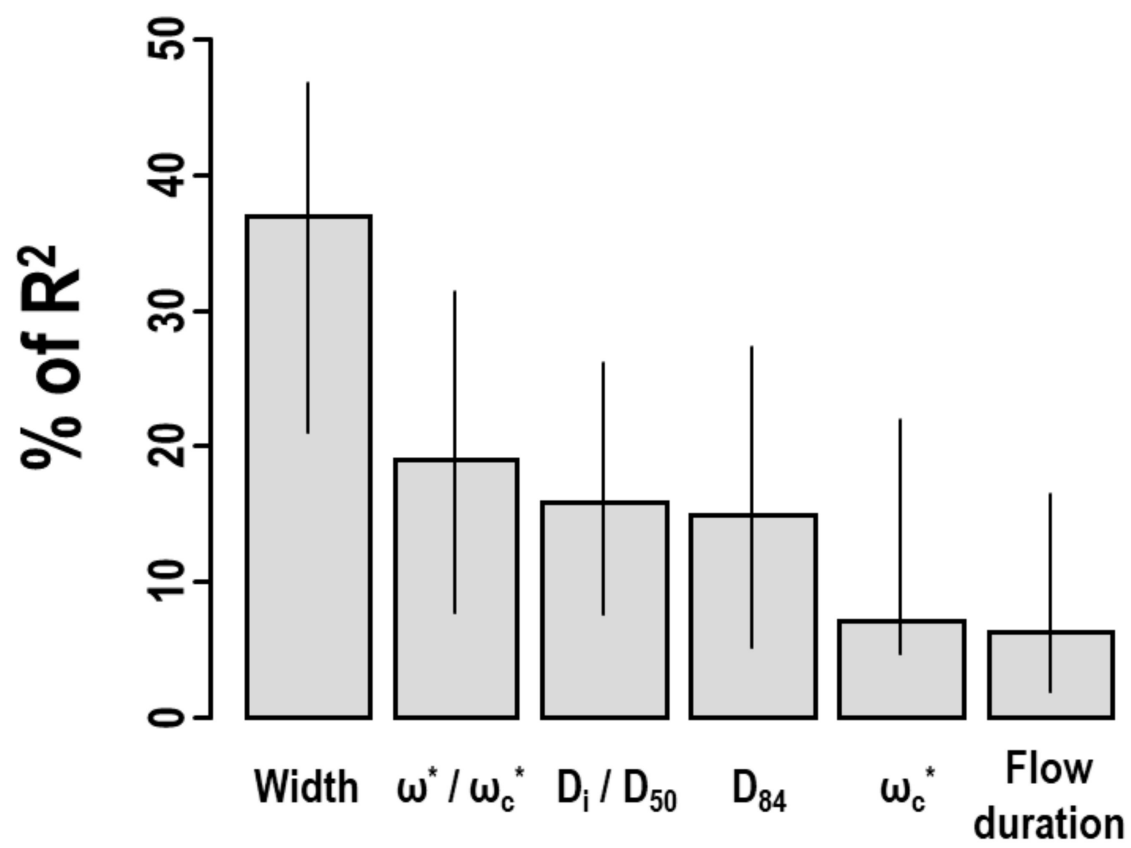

Figure 1. Shares of variance to different variables included in Equation (13).

In addition, we compared our model (Equation (13)) to two simple regression models relating (i) mean travel distances to stream power (Equation (14)) and (ii) stream power times competent flow duration (Equation (15)). The comparison suggests that Equation (13) considerably increases the variance explanation: $R^{2}=0.87$ in comparison to $R^{2}=0.18$ (Equation (14)) and $R^{2}=0.03$ (Equation (15)) (Figure 2, Table 3), even when channel morphology is accounted for. 

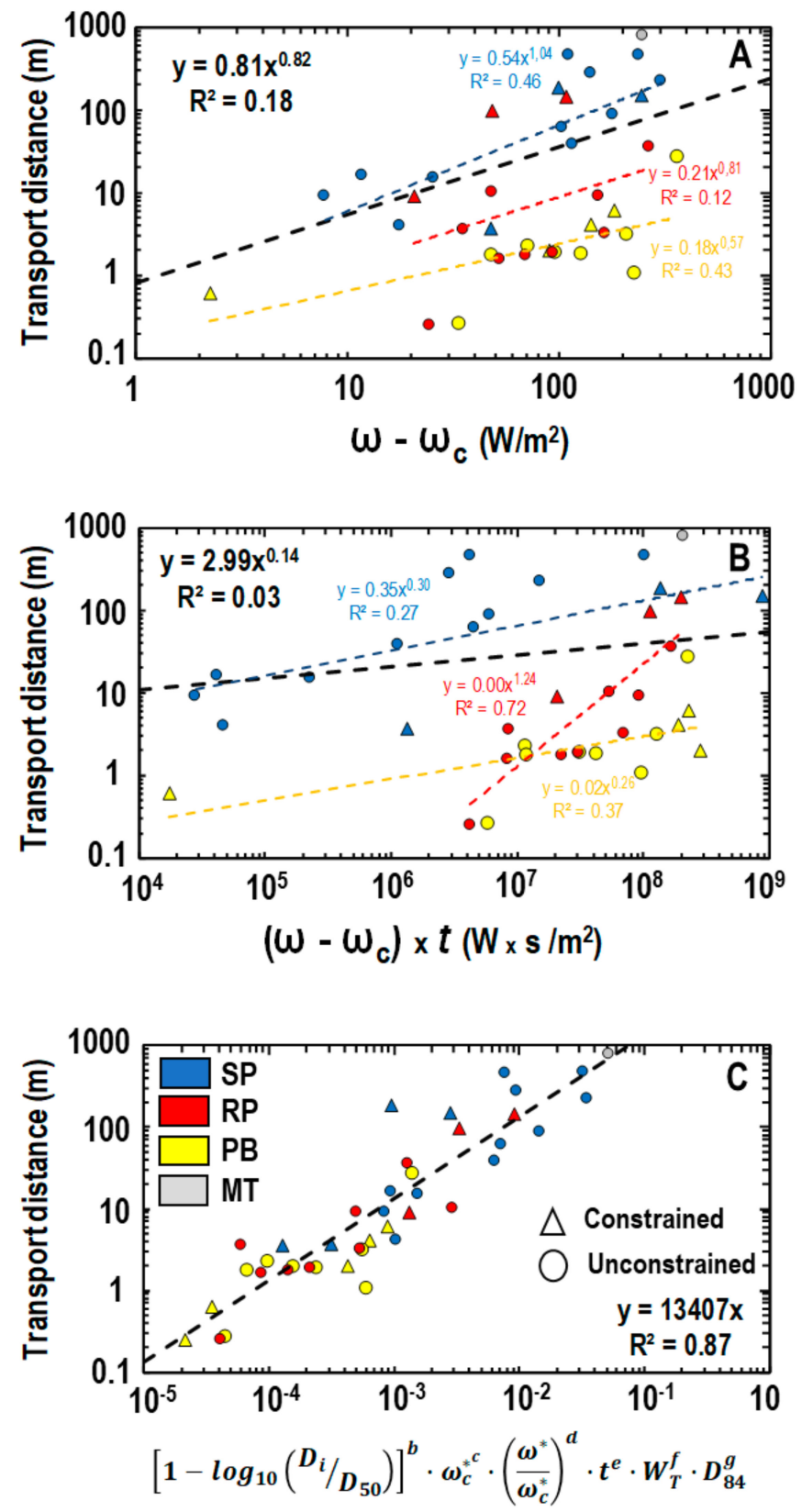

Figure 2. Relationships between measured tracer travel lengths and (A) stream power, (B) stream power times duration of competent flow duration, and (C) Equation (13). SP: Step-Pool. RP: Riffle-Pool. PB: Plane-Bed. MT: Multi-Thread.

Table 3. Intercepts and coefficients fitted for Equations (13)-(15).

\begin{tabular}{ccccccccc}
\hline Model & Intercept & $\boldsymbol{b}^{\mathbf{1}}$ & $\boldsymbol{c}^{\mathbf{2}}$ & $\boldsymbol{d}^{\mathbf{3}}$ & $\boldsymbol{e}^{\mathbf{4}}$ & $f^{5}$ & $\boldsymbol{l}^{\mathbf{6}}$ & $\boldsymbol{R}^{\mathbf{2}}$ \\
\hline Equation (13) (all) & 13406.86 & 4.859 & 2.742 & 1.931 & 0.167 & 2.878 & 3.239 & 0.87 \\
$\left(\omega^{*}-\omega_{c}^{*}\right)($ all) & 0.81 & & & 0.82 & & & & 0.18 \\
$\left(\omega^{*}-\omega_{c}^{*}\right)(\mathrm{RP})$ & 0.21 & & & 0.81 & & & & 0.12 \\
$\left(\omega^{*}-\omega_{c}^{*}\right)(\mathrm{PB})$ & 0.18 & & & 0.57 & & & & 0.43 \\
$\left(\omega^{*}-\omega_{c}^{*}\right)(\mathrm{SP})$ & 0.54 & & & 1.04 & & & & 0.46 \\
\hline
\end{tabular}


Table 3. Cont.

\begin{tabular}{llll}
\hline$\left(\omega^{*}-\omega_{c}^{*}\right) \times t($ all $)$ & 2.99 & 0.14 & 0.03 \\
$\left(\omega^{*}-\omega_{c}^{*}\right) \times t(\mathrm{RP})$ & 0.00 & 1.24 & 0.72 \\
$\left(\omega^{*}-\omega_{c}^{*}\right) \times t(\mathrm{~PB})$ & 0.02 & 0.26 & 0.37 \\
$\left(\omega^{*}-\omega_{c}^{*}\right) \times t(\mathrm{SP})$ & 0.35 & 0.30 & 0.27 \\
\hline
\end{tabular}

${ }^{1}$ The model coefficient defining how mean travel lengths scale to tracer size. ${ }^{2}$ The model coefficient defining how mean travel lengths scale to critical dimensionless stream power $\left(\omega_{c}{ }^{*}\right){ }^{3}$ The model coefficient defining how mean travel lengths scale to tracer size $\omega^{*} / \omega_{c}{ }^{*}$ or $\left(\omega^{*}-\omega_{c}{ }^{*}\right) .{ }^{4}$ The model coefficient defining how mean travel lengths scale to the duration of the competent flow $(t) .{ }^{5}$ The model coefficient defining how mean travel lengths scale to the channel width. ${ }^{6}$ The model coefficient defining how mean travel lengths scale to $D_{84}$; RP: Riffle-Pool Channels. PB: Plane-Bed Channels. SP: Step-Pool Channels. (all): All data.

Additionally, Equation (13) provides better scores on model precision and accuracy than the simple regression models, which were based on excess stream power (Equation (14)) or excess stream power times flow duration (Equation (15)) (Figure 3).
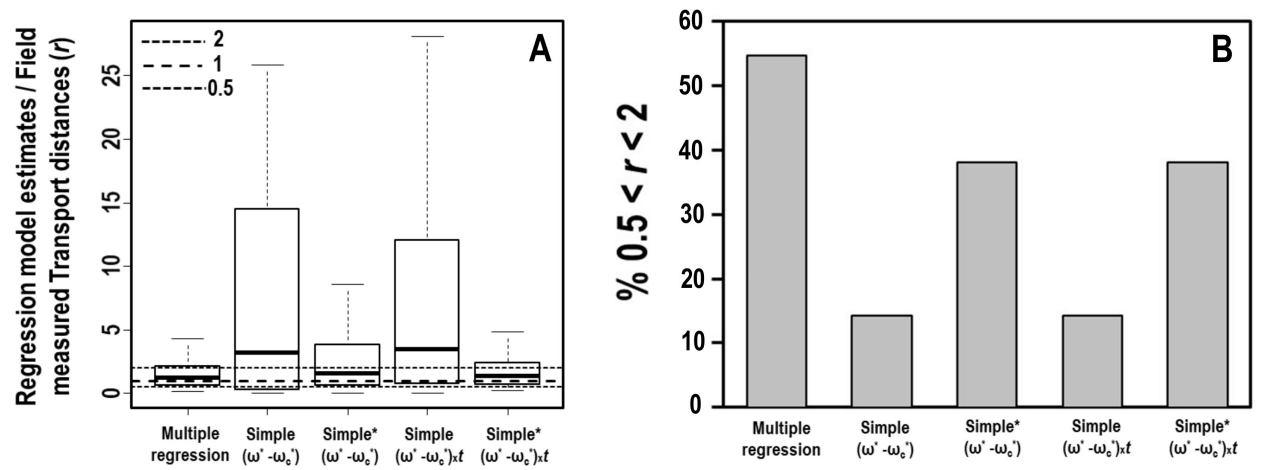

Figure 3. Assessment of the regression model robustness using jackknife resampling procedures: (A) discrepancy between model estimates and field measurements, and (B) percentage of data where model estimates are between 0.5 and 2 of field measurements. $\left(^{*}\right)$ Results of applying the simple regression model independently to each group of channel morphologies (plane-bed, riffle-pool, step-pool, and multi-thread).

\subsection{Influence of Channel Morphology and Experimental Conditions}

Data tend to segregate, according to channel morphology, when travel lengths are plotted against excess stream power (or excess stream power times flow duration). The step-pool data is plotted in the upper envelope of the point cloud, while riffle-pool and plane bed data sit on the lower envelope (Figure 2A,B). Statistical significance also increases when simple regression is performed separately for each morphological group (Figure 2A,B, Table 3), which underpins that morphology has an important effect on travel length (model fitting two-way ANOVA test, $p$-value $<0.05$ ). Additionally, values of EEI tend to be larger in riffle-pools than in step-pools in the compiled dataset (Figure 4), which indicates that riffle-pool systems require larger energy expenditure to move tracers. Conversely, data on travel-length from different morphologies collapse when plotted in relation to Equation (13). Somehow, the morphological signature on travel lengths seems to vanish when using Equation (13). 


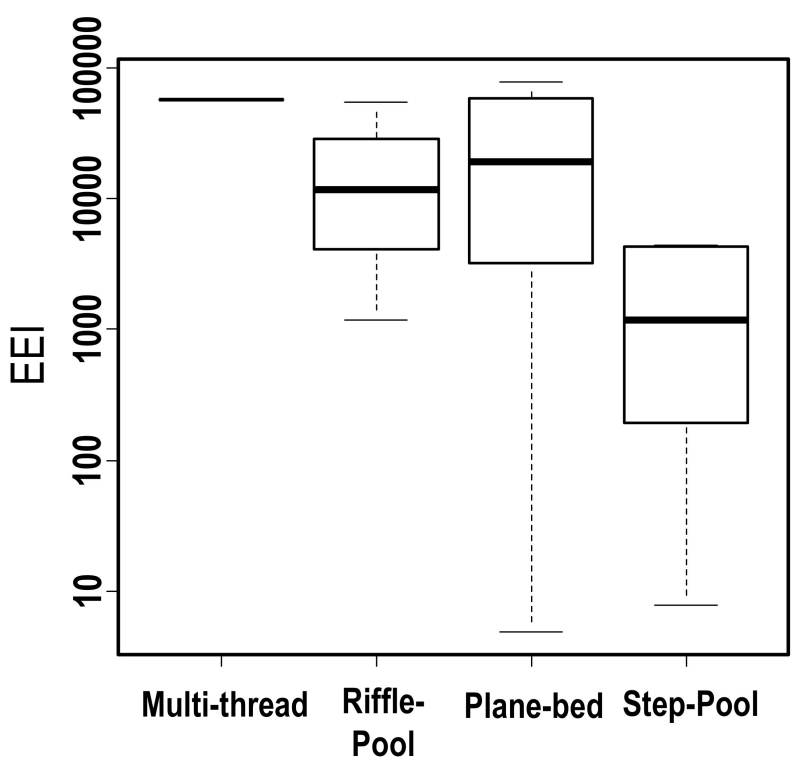

Figure 4. Differences in EEI (see Section 2.3 in the text for a description of this index) according to channel morphology for the compiled data set.

The different behaviors between the simple and the multiple regression model, therefore, need further discussion. Within the compiled data set, channel width tends to be larger and $D_{84}$ tends to be finer in riffle-pools compared to step-pools and plane-beds (Figure 5A,B). Dimensionless critical stream power is also larger in riffle-pools than in step-pools (Figure 5C). Additionally, differences in competent flow duration between different morphologies, particularly between riffle-pool and step-pool channels, can also be observed (Figure 5D). Hence, all the parameters incorporated into Equation (13) show differences, according to channel-morphology. This may explain why data from different morphologies collapse into the same trend when Equation (13) is used.
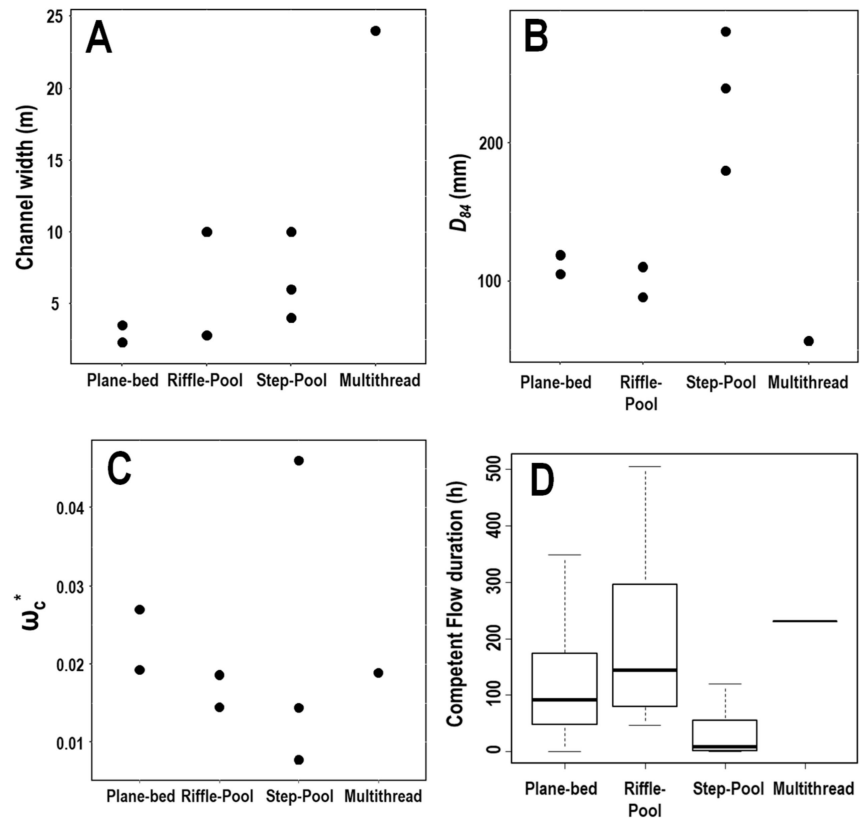

Figure 5. Differences in (A) channel width, (B) $D_{84},(\mathbf{C})$ dimensionless critical stream power, and (D) and flow duration, according to channel morphology for the compiled data set. 
To check that these trends are not merely a product of the data set used in the paper, we look at a wider available database, Bedloadweb at https://en.bedloadweb.com, which encompasses 116 gravel-bed rivers worldwide, and we observed similar trends (Figure 6). We, thus, conclude that Equation (13) implicitly incorporates channel morphology in its formulation, notably through width and $D_{84}$.
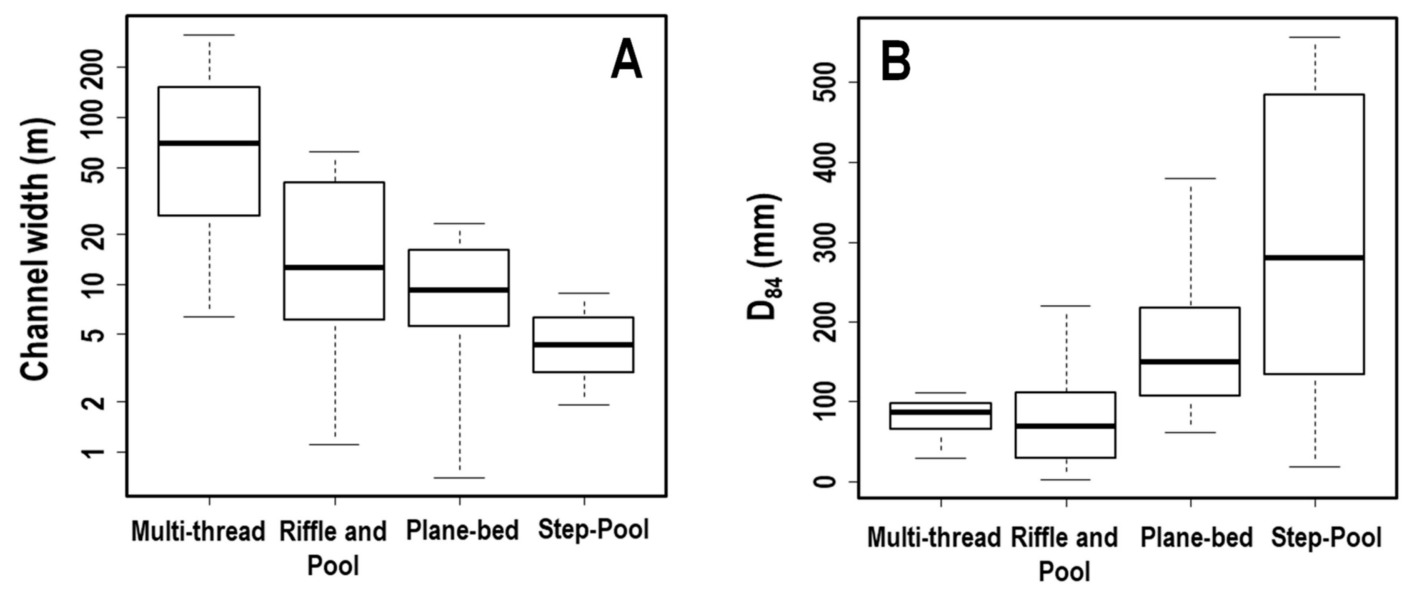

Figure 6. Differences in channel width (A) and $D_{84}(\mathbf{B})$ of data from www.bedloadweb.com.

A graphical comparison shows differences between a 'constrained-tracer' and 'unconstrained-tracer' in case of step-pools: 'unconstrained-tracers' plot higher when mean travel lengths are plotted as a function of stream power and stream power times competent flow duration (Figure 2A,B). In contrast, no clear differences are observed between the two data sets in the cases of riffle-pools and plane-beds. Yet again, no differences between both experimental conditions can be observed when using Equation (13) (Figure 2C).

\section{Discussion}

\subsection{Variability in Particle Travel Distances}

Equation (13) scales the event-based bedload volumes to the geometry of the active layer. The subsequent multiple regression analysis confirmed that the model provides a statistically significant description of the travel length datasets against which the model was tested. Furthermore, Equation (13) explains a larger amount of data variance than simple regression equations based on excess stream power, or excess stream power times competent flow duration, which is the approach more generally followed with many previous tracer studies [17].

Equation (13) relates travel length to six independent predictors: channel width, $D_{84}$, tracer size, the $\omega^{*} / \omega_{c}^{*}$ ratio, competent flow duration, and $\omega_{c}^{*}$. Channel geometry (proxied by channel width) is the parameter explaining the largest differences in travel length (Figure 1), which is followed by hydraulic forcing. The bed structure (proxied by critical stream power) and tracer size appear to play a less determinant role compared to hydraulic constraints and channel dimensions. The channel shows a positive power scaling with travel length. On the one hand, channel width provides a measure of the hydraulic geometry of the study sections. Hence, the longest travel lengths are expected in larger channels due purely to their larger dimensions. On the other hand, the length-scale of the channel determines the average spacing between macro-bedforms [30], which, in turn, is typically argued to control travel length (e.g., Pyrce and Ashmore work [32]).

Travel lengths also show positive power scaling with $D_{84}$. The role of $D_{84}$ on tracer travel lengths is interesting because it is related to the depth of scour, and, at the same time, prevents entrainment from occurring. That said, a larger $D_{84}$ involves a thicker active layer (through scaling the depth caused by particle entrainment). Furthermore, $D_{84}$ is related to the length scale of the major grains on the streambed, and large protruding clasts act as obstacles that may stop and entrap sediment [63], 
which may increase the chances of a given tracer becoming buried. In principle, both situations may decrease the amount of tracer displacement, so travel lengths should show a negative relationship to $D_{84}$. However, larger grains control the mobility of the bed-surface sediment in gravel and cobble streams, and a larger $D_{84}$ may involve a more stable streambed [66,67], which increases the chances of tracers showing pass-over behavior. In this regard, travel length also showed a positive scaling to $\omega_{c}{ }^{*}$, which is likely to be a relevant measure of bed-surface stability. Thus, the pass-over behavior of tracers, promoted by an increase in streambed stability with larger $D_{84}$, appears to compensate for the potential influence of deeper tracer burial in thicker active layers, and may explain the observed positive scaling of the travel length with $D_{84}$.

Moreover, travel length also shows a positive dependence on peak stream power. The results corroborate the strong control that flow strength exerts on travel length, which has been previously outlined $[17,22,26]$. This seems clear, insofar that hydraulic forces provide the energy required to put clasts into motion and maintain bedload transport. Travel length also shows a positive dependence on flow duration. Time duration of the competent flow is relevant to bedload fluxes in terms of its contribution to the total flow energy [80]. In this regard, travel distances coming from tracer studies represent the distance travelled by tagged stones over a time interval that corresponds to flow duration. Therefore, an influence of flow duration on mean travel length should be expected. Lastly, travel length also shows a positive dependence on the relative tracer size, in that travel length increases as tracer size decreases relative to the bed surface (as introduced in Section 2.1). However, the dependence found here (regression exponent $b=4.86$ ) is stronger than that documented by Church and Hassan [63] and Hassan and Church [64] $(b=1.35)$.

\subsection{Morphological Control of Travel Length}

The influence of channel morphology on particle displacement is well established in the tracer literature. The idea is highly intuitive, since different morphological patterns and channel platform configurations are composed of diverse cross-sectional topographies, which determine the variability in 3D flow structures and sorting patterns $[4,81,82]$. In fact, it has been observed that the mean travel distance of tagged stones is associated with the dominant length scale of macro-bedforms for channel forming floods $[24,29,32,33,63,72,83]$.

The data compiled in this study collapse when travel lengths are set against Equation (13), with little differences, according to channel morphology (Figure 2C). This is surprising, considering that the data encompass a wide range of channel morphologies, from small step-pool systems to large, wandering rivers. However, as indicated above (Figures 5 and 6), the parameters included in Equation (13) show differences, according to channel morphology. Doubt remains as to whether these trends are an artefact of the specific data set or the observed differences are intrinsic of natural rivers. Step-pool systems are, in general, smaller and narrower than riffle-pool channels. Furthermore, step-pools are featured by boulders and coarser keystones and, consequently, coarser $D_{84}$ and larger $\omega_{c}^{*}$ values are expected. Lastly, step-pool streams drain, on average, into smaller drainage areas compared to other channel types, and are characterized by a flashier regime, with short storm flows (see the discussion by Comitti [17]), which likely have an effect on the reported shorter flow duration in our step-pool data. In summary, our analysis (see Section 3.1) outlined how all the parameters included in Equation (13) are significant in explaining differences in travel distance between different channels. Consequently, if these parameters are assumed to be a proxy of channel morphology, it can be concluded that Equation (13) actually incorporates the role of morphological controls into travel length. However, we are aware that this hypothesis needs further assessment from field data in new tracer studies which, unfortunately, are less and less available.

In order to take the analyses of morphological controls on gravel transport further, we defined the "Energy Expenditure Index" (EEI). Values of the EEI are larger in riffle-pools and multi-thread channels than in step-pools in the compiled dataset (Figure 4), which indicates that multi-thread and riffle-pool systems required larger energy expenditure to move tracers. Previous studies have examined 
gravel dispersion in riffle-pool systems [14,35,54,72], reporting differences in tracer travel distances and depositional loci, according to source areas [14,31,35] and grain-size sorting [35]. Similarly, Lamarre and Roy [24] and Schmidt and Ergenzinger [84] assessed gravel dispersion in steep slope mountain streams, where gravel tends to become entrapped in pools $[84,85]$ and/or behind immobile boulders and large keystones [86]. However, streamlines and flow trajectories tend to concentrate particles into preferred gravel paths in coarse bed rivers, and these preferential sediment transport lines are strongly influenced by dominant channel morphologies [24,35]. Consequently, macro-bedforms have two opposing effects on gravel propagation. On the one hand, large boulders and gravel-bars can entrap sediment and slow down their transfer downstream. On the other hand, macro-bedforms tend to concentrate flow and sediment into preferential paths, which promotes a faster sediment conveyance when particles 'fall' into them. EEI values are slightly lower in riffle-pools compared to plane-bed channels (i.e., which have less influence of bedforms). This outlines the importance of preferential paths on particle conveyance. However, they are larger compared to step-pool streams, which may indicate the importance of the trapping process in riffle-pool units. Conversely, the lower EEI values in step-pool systems compared to plane-beds seem to suggest a lower importance of sediment trapping in relation to particle conveyance through sediment paths.

\subsection{Structural Controls on Travel Length}

Particle clustering has an important impact on gravel mobility. These kinds of structures are often reported to increase the thresholds for sediment motion [22,38,39,87-89]. In order to incorporate this into the analysis, we introduced $\omega_{c}{ }^{*}$ as the predictor parameter in the regression model. This parameter was obtained for each selected site from the information provided in the original studies, since it was established by authors from field observations on incipient tracer motion. The analysis suggested that this parameter is significant in explaining $~ 10 \%$ of the variance in tracer data, which highlights the appreciable role of sediment structures in gravel transport.

As previously explained (Section 2.2), we also classified data into two groups: 'constrained-tracer' and 'unconstrained-tracer' data, depending on whether they corresponded to first or subsequent displacements after tracer seeding. Globally, no differences are observed between both groups of data after fitting travel length values to Equation (13) (Figure 2C). This suggests that the variability related to experimental conditions is diluted by the variability introduced by channel dimensions, $D_{84}$, tracer size, and channel morphology. Nevertheless, when the different morphologies are considered separately, differences are observed between 'unconstrained' and 'constrained' tracer conditions in step-pool channels. This finding resembles the difference between structured and travelling bedload proposed by Piton et al. and Piton and Recking [90,91], for step-pool channels. No differences could be identified in the riffle-pool and plane-bed channels. Similar trends in tracer data, according to channel morphology and experimental conditions, were reported by Vázquez-Tarrío et al. [29].

In this regard, critical stream power is likely to evolve through time, since flood history has an important role in bed particle structuration $[43,45,46,88]$. Unfortunately, information on antecedent bed conditions is very scarce in published tracer studies. In addition, the duration of tracer studies is rather low in comparison to the required time for particle mixing in the bed (Table 1), which may have affected tracer displacement in the selected data set, increasing the importance of pass-over behavior.

\subsection{Methodological Uncertainties}

Predictors included in Equation (13) explain $\sim 85 \%$ of the variability in the compiled tracer data. Hence, there remains around $15 \%$ of non-explained scatter. Some of this remaining scatter may relate to methodological uncertainties. The way flow discharge and other parameters are measured and reported may not be totally homogeneous across the papers referred to in this research. Another constraint may be related to the exact morphological setting where tracers were seeded (i.e., channel, riffle, bar-head, and bar-tail). Some authors reported differences in tracer travel distances between riffles and pools [14,31,35], and low-flow channels and gravel bars [73]. In all the study cases, tracers 
were initially seeded in a very similar way, along transverse lines and crossing several morphological units (Table 1). However, once tracers moved, they were 'free' to find new depositional loci, and this may have introduced some variability in the subsequent displacements.

Furthermore, metrics of stream power used in the present analysis are section-average rather than point specific. However, tracers are spatially distributed and they likely experience a wide range of local hydraulic conditions in the course of a transport episode. Thus, one could argue that there is some limitation in assuming averaged measures for hydraulics when dealing with tracer data. Nevertheless, in this paper, we worked with mean travel lengths, so it was meaningful to compare mean travel lengths to average hydraulic parameters. It is worth noticing, too, that data on flow duration used in this research were based on information provided by the original papers, i.e., total time passing above a competence threshold was defined for the entire riverbed in all cases. However, some authors highlighted that a dependency exists between competent duration and grain-size [38,49]. This may explain some of the observed variance. Nevertheless, the influence of particle size relative to bed size on travel lengths is already incorporated into the model (see Equation (7) in Section 2.1), so it could be considered that the size-dependency of flow duration is absorbed by the parameter scaling mean travel length to tracer size.

Furthermore, tracer stones accurately represent bed-material flux only after they are representatively mixed throughout the entire potentially movable bed layer, which means to the maximum scour depth [92]. In practice, this means that they have been exposed to several competent floods, which, occasionally, is not the case after some years $[25,47,93,94]$. The mixing time is five to 10 years (as per Ferguson et al. findings [47]), which exceeds the duration of almost all available studies. Consequently, some results may be influenced by dominantly short periods of deployment, and could misrepresent long-term trends.

Moreover, and as previously stated, the study focuses only on datasets showing a recovery rate $>75 \%$, to avoid inaccuracies in travel length linked to low recovery rates. However, the adopted approach poses a methodological issue. The low recovery ratios can result from (i) tracer burial below the range of particle detection, and (ii) frontrunners quickly passing-over the study reach, along with how it changes in relation to channel morphology and experimental conditions. For instance, tracer burial in riffle-pool channels may be controlled by the mechanisms involved in bar accretion and/or gravel-sheet migration, whereas, in step-pool channels, these mechanisms are absent $[29,90]$. As far as we know, there is no way to discriminate between experiments where low tracer recoveries are mainly due to frontrunners quickly passing over the study reach, and those studies where low tracer recoveries are controlled by tracers getting buried deeper than the typical detection ranges of tracking devices. More research is needed to shed light into which mechanism (burial or frontrunners) is behind tracer loss during the first transport episodes after tracer seeding, whether this depends on channel morphology, and/or if the dominant process evolves through time. The recent development and use of active-RFID tagging methods that enlarge detection ranges is promising in this direction [18].

\section{Conclusions}

The quantitative understanding of particle travel length in gravel-bed rivers is, at least, as relevant as quantifying the bedload volumes for many scientific and applied topics, such as investigating macroinvertebrate drift or designing gravel augmentation schemes. Several empirical relationships between travel distance and different flow metrics have been reported in the literature. However, particle tracking is the only available tool to tackle this issue. In this paper, we hypothesized that particle travel length is a dependent variable of channel width, grain-size, critical discharge, peak stream power, and flow duration, accounting for the scaling of event-based bedload volumes with active layer dimensions. We tested this using a dataset of tagged stones (tracers). Results indicate that mean travel distance of gravel can be explained, to a considerable extent, by the six considered variables of peak stream power, flow duration, critical discharge, channel width, tracer, and bed sediment size. If site-specific factors (i.e., channel morphology, surface texture) are considered stable, then flow magnitude (i.e., transport stage) and duration account for almost all the variance in travel length during 
transport episodes. This may help explain why previous tracer research found strong correlations between transport distances and time-integrated flow metrics in case studies (e.g., Schneider et al. [26]), but large scatter in review studies (e.g., Hassan and Bradley or Vázquez-Tarrío et al. [17,29]) and a stronger correlation with channel dimensions [29,30]. The work provides insights into the different controls on gravel transport in coarse bed rivers and recalls some limitations of the tracer method and available tracer data.

The recent work by Vericat et al. [58] demonstrates how virtual velocity derived from tracer step lengths can be coupled with the analysis of volumetric changes derived from diachronic digital elevation models in order to obtain spatially distributed bedload transport rates. In this regard, the present analysis provides a tool for improving bedload estimations in gravel-bed rivers and constitutes a step forward toward predicting particle travel length in gravel-bed rivers, and its further application to river restoration and gravel augmentation.

Author Contributions: Conceptualization, V.T.D. and B.R.J. Methodology, V.T.D. and B.R.J. Formal analysis, V.T.D. and B.R.J. Writing—original draft preparation, V.T.D. Writing—review and editing, V.T.D. and B.R.J. Visualization, V.T.D. and B.R.J. Supervision, B.R.J. Funding acquisition, V.T.D. and B.R.J.

Funding: The present work has been possible thanks to the financial support provided by the grant ACB17-44, co-funded by the post-doctoral 'Clarín' program-FICYT (Government of the Principality of Asturias) and the Marie Curie Co-Fund. This research was partly undertaken through the MorphPeak (CGL2016-78874-R) project funded by the Spanish Ministry of Economy and Competiveness and the European Regional Development Fund Scheme. Authors acknowledge the support from the Economy and Knowledge Department of the Catalan Government through the Consolidated Research Group 'Fluvial Dynamics Research Group' -RIUS (2017 SGR 459), as well as support from the project RIVERCHANGES-CGL2015-68824-R (MINECO/FEDER, UE).

Acknowledgments: We would like to thank Armando García-Mendoza Ortega and Pablo David García for their always inspiring teaching on fundamental physics, and Mark Smith for the review of the first version of this manuscript.

Conflicts of Interest: The authors declare no conflict of interest. The funders had no role in the design of the study, in the collection, analyses, or interpretation of data, in the writing of the manuscript, or in the decision to publish the results.

\section{Nomenclature}

b Model coefficient defining how travel lengths scale to the tracer size

c Model coefficient defining how travel lengths scale to $\omega_{c}{ }^{*}$

d Model coefficient defining how travel lengths scale to $\omega^{*} / \omega_{\mathcal{c}}^{*}$

$\mathrm{D}_{\mathrm{i}} \quad$ Tracer size

$\mathrm{D}_{50} \quad$ Median diameter of the surface grain-size distribution

$\mathrm{D}_{84} \quad$ 84-th percentile of the surface grain-size distribution

$\gamma_{\mathrm{H}} \quad$ Parameter multiplying $D_{84}$ and characterizing the active layer depth

e Model coefficient defining how travel lengths scale to $t$

f Model coefficient defining how travel lengths scale to $W_{T}$

g Gravity acceleration

$\mathrm{h} \quad$ Average depth of the active layer

$1 \quad$ Model coefficient defining how travel lengths scale to $D_{84}$

L Average distance travelled by the bedload

$\mathrm{L}_{\mathrm{Di}} \quad$ Average transport distance of individual grains of diameter $D_{i}$

$L_{D 50}$ Average transport distance of the median grain-size

$\mathrm{p} \quad$ Fractional porosity of channel sediment

Q Water discharge

$\mathrm{Q}_{\mathrm{c}} \quad$ Threshold discharge for incipient sediment motion

$\mathrm{q}_{\mathrm{s}} \quad$ Average bedload rate of the transport episode

$\mathrm{Q}_{\mathrm{s}} \quad$ Event-based bedload volumes

S Channel slope

$\mathrm{t}$ Time duration of the competent flow 
$\mathrm{W}_{\mathrm{a}} \quad$ Mean active channel width

$\mathrm{W}_{\mathrm{T}} \quad$ Total channel width

$\gamma_{\mathrm{W}} \quad$ Fraction of the total channel width involved in the bedload

$\omega$ Specific stream power

$\omega_{\mathrm{c}} \quad$ Threshold value of $\omega$ for incipient sediment motion

$\omega^{*} \quad$ Dimensionless specific stream power

$\omega_{\mathrm{C}}{ }^{*}$ Threshold value of $\omega^{*}$ for incipient sediment motion

\section{References}

1. Church, M. Bed material transport and the morphology of alluvial river channels. Annu. Rev. Earth Planet. Sci. 2006, 34, 325-354. [CrossRef]

2. Rice, S.; Johnson, M.F.; Reid, I. Animals and the geomorphology of gravel-bed rivers. In Gravel-bed Rivers: Processes, Tools, Environments; Church, M., Biron, P., Roy, A.G., Eds.; Wiley and Sons: Chichester, UK, 2012; pp. 225-241.

3. Recking, A. An analysis of nonlineary effects on bedload transport prediction. J. Geophys. Res. Earth Surf. 2013, 118, 1264-1281. [CrossRef]

4. Ferguson, R.I. The missing dimension: Effects of lateral variation on 1-D calculations of fluvial bedload transport. Geomorphology 2003, 56, 1-14. [CrossRef]

5. Parker, G. Chapter 3: Transport of gravel and sediment mixtures. In Manual 110. Sedimentation Engineering: Processes, Measurements, Modelling and Practice; García, M., Ed.; American Society of Civil Engineers: Reston, VA, USA, 2008; pp. 165-244.

6. Yager, E.M.; Venditti, J.G.; Smith, H.J.; Schmeeckle, M.W. The trouble with shear stress. Geomorphology 2018, 323, 41-50. [CrossRef]

7. Gomez, B.; Naff, R.L.; Hubell, D.W. Temporal variations in bedload transport associated with the migration of bedforms. Earth Surf. Process. Landf. 1989, 14, 135-156. [CrossRef]

8. Hoey, T.B. Temporal variations in bedload transport rates and sediment storage in gravel-bed rivers. Prog. Phys. Geogr. 1992, 16, 319-338. [CrossRef]

9. Kuhnle, R.A. Chapter 5: Unsteady transport of sand and gravel mixtures. In Advances in Fluvial Dynamics and Stratigraphy; Carling, P.A., Dawson, M.R., Eds.; John Wiley and Sons Ltd.: Hoboken, NJ, USA, 1996; pp. 183-201.

10. Recking, A.; Liébault, F.; Peteuil, C.; Jolimet, T. Testing several bedload transport equations with consideration of time scales. Earth Surf. Process. Landf. 2012, 37, 774-789. [CrossRef]

11. Laronne, J.B.; Carson, M. Interrelationships between bed morphology and bed material transport for a small, gravel-bed channel. Sedimentology 1976, 23, 67-85. [CrossRef]

12. Hassan, M.; Schick, A.; Laronne, J. The recovery of flood-dispersed coarse sediment particles. Catena suppl. 1984, 5, 53-162.

13. Ashworth, P.J. Bedload Transport and Channel Change in Gravel-Bed Rivers. Ph.D. Thesis, University of Stirling, Scotland, UK, 1987.

14. Sear, D. Sediment transport processes in pool-riffle sequences. Earth Surf. Process. Landf. 1996, 21, $241-262$. [CrossRef]

15. Hassan, M.A.; Ergenzinger, P. Use of Tracers in Fluvial Geomorphology. In Tools in Fluvial Geomorphology; Kondolf, G.M., Piegay, H., Eds.; John Wiley and Sons: Hoboken, NJ, USA, 2003.

16. Hassan, M.A.; Roy, A. Use of Tracers in Fluvial Geomorphology. In Tools in Fluvial Geomorphology, 2nd ed.; Kondolf, G.M., Piegay, H., Eds.; John Wiley and Sons: Hoboken, NJ, USA, 2015.

17. Hassan, M.; Bradley, D.N. Geomorphic controls on tracer particle dispersion in gravel-bed rivers. In Gravel-Bed Rivers. Processes and Disasters; Tsutsumi, D., Laronne, J.B., Eds.; Wiley-Blackwell: Chichester, UK, 2017; pp. 439-466.

18. Cassel, M.; Dépret, T.; Piegay, H. Assessment of a new solution for tracking pebbles in rivers based on active RFID. Earth Surf. Process. Landf. 2017, 42, 1938-1951. [CrossRef]

19. Wong, M.; Parker, G.; DeVries, P.; Brown, T.M.; Burges, J.S. Experiments on dispersion of tracer stones under lower-regime plane-bed equilibrium bedload transport. Water Resour. Res. 2007, 43. [CrossRef] 
20. Reid, I.; Layman, J.T.; Frostick, L.E. The continuous measurement of bedload discharge. J. Hydraul. Res. 1980, 18, 243-279. [CrossRef]

21. Helly, E.J.; Smith, W. Development and Calibration of a Pressure-Difference Bedload Sampler. US Geological Survey Open-File Report; U. S. Dept. of the Interior, Geological Survey, Water Resources Division: Menlo Park, CA, USA, 1971.

22. Hassan, M.A.; Church, M.; Ashworth, P.J. Virtual rate and mean distance of travel of individual clasts in gravel-bed channels. Earth Surf. Process. Landf. 1992, 17, 617-627. [CrossRef]

23. Lenzi, M.A. Displacement and transport of marked pebbles, cobbles and boulders during floods in a steep mountain stream. Hydrol. Process. 2004, 18, 1899-1914. [CrossRef]

24. Lamarre, H.; Roy., A.G. The role of morphology on the displacement of particles in a step-pool river system. Geomorphology 2008, 99, 270-279. [CrossRef]

25. Haschenburger, J.K. Tracing river gravels: Insights into dispersion from a long-term field experiment. Geomorphology 2013, 200, 121-131. [CrossRef]

26. Schneider, J.; Turowski, J.; Rickenmann, D.; Hegglin, R.; Arrigo, S.; Mao, L.; Kirchner, J. Scaling relationships between bedload volumes, transport distances, and stream power in steep mountain channels. J. Geophys. Res. Earth Surf. 2014, 119, 533-549. [CrossRef]

27. Phillips, C.B.; Martin, R.L.; Jerolmack, D.J. Impulse framework for unsteady flows reveals superdiffusive bedload transport. Geophys. Res. Lett. 2013, 40, 1328-1333. [CrossRef]

28. Phillips, C.B.; Jerolmack, D.J. Dynamics and mechanics of bed-load tracer particles. Earth Surf. Dyn. 2014, 2, 513-530. [CrossRef]

29. Vázquez-Tarrío, D.; Recking, A.; Liébault, F.; Tal, M.; Menéndez-Duarte, R. Particle transport in gravel-bed rivers: Revisiting passive tracer data. Earth Surf. Process. Landf. 2019, 44, 112-128.

30. Beechie, T.J. Empirical predictors of annual bedload travel distance, and implications for salmonid habitat restoration and protection. Earth Surf. Process. Landf. 2001, 26, 1025-1034. [CrossRef]

31. Milan, D.J.; Heritage, G.L.; Large, A.R.G. Tracer pebble entrainment and deposition loci: Influence of flow character and implications for riffle-pool maintenance. In Sediment Flux to Basins: Causes, Controls and Consequences; Jones, S.J., Frostick, L.E., Eds.; Geological Society of London Special Publications 191; The Geological Society: London, UK, 2002; pp. 133-148.

32. Pyrce, R.S.; Ashmore, P.E. The relation between particle path length distributions and channel morphology in gravel-bed streams: A synthesis. Geomorphology 2003, 56, 167-187. [CrossRef]

33. Pyrce, R.S.; Ashmore, P.E. Particle path length distributions in meandering gravel-bed streams: Results from physical models. Earth Surf. Process. Landf. 2003, 28, 951-966. [CrossRef]

34. Pyrce, R.S.; Ashmore, P.E. Bedload path length and point bar development in gravel-bed river models. Sedimentology 2005, 52, 839-857. [CrossRef]

35. Milan, D.J. Sediment routing hypothesis for pool-riffle maintenance. Earth Surf. Process. Landf. 2013, 38, 1623-1641. [CrossRef]

36. Hassan, M.A.; Church, M.; Schick, A.P. Distance of movement of coarse particles in gravel-bed streams. Water Resour. Res. 1991, 27, 503-511. [CrossRef]

37. Milan, D.J. Virtual velocity of tracers in a gravel-bed river using size-based competence duration. Geomorphology 2013, 198, 107-114. [CrossRef]

38. Brayshaw, A.C.; Frostick, L.E.; Reid, I. The hydrodynamics of particle clusters and sediment entrainment in coarse alluvial channels. Sedimentology 1983, 30, 137-143. [CrossRef]

39. Reid, I.; Frostick, L.E.; Brayshaw, A.C. Microform roughness elements and the selective entrainment and entrapment of particles in gravel-bed rivers. In Dynamics of Gravel-Bed Rivers; Billi, P., Hey, R.D., Thorne, C.R., Tacconi, P., Eds.; Wiley: Chichester, UK, 1992; pp. 253-266.

40. Powell, D.M.; Ashworth, P.J. Spatial pattern of flow competence and bedload transport in a divided gravel-bed river. Water Resour. Res. 1995, 31, 741-752. [CrossRef]

41. Church, M.; Hassan, M.A.; Wolcott, J.F. Stabilizing self-organized structures in gravel-bed stream channels: Field and experimental observations. Water Resour. Res. 1998, 34, 3169-3179. [CrossRef]

42. Turowski, J.; Yager, E.M.; Badoux, A.; Rickenmann, D.; Molnar, P. The impact of exceptional events on erosion, bedload transport and channel stability in a step-pool channel. Earth Surf. Process. Landf. 2009, 34, 1661-1673. [CrossRef] 
43. Ockelford, A.; Haynes, H. The impact of stress history on bed structure. Earth Surf. Process. Landf. 2013, 38, 717-727. [CrossRef]

44. Mao, L.; Dell'Agnese, A.; Surian, N. Sediment motion and velocity in a glaciar-fed stream. Geomorphology 2017, 291, 69-79. [CrossRef]

45. Mao, L. The effects of flood history on sediment transport in gravel-bed rivers. Geomorphology 2018, 322, 196-205. [CrossRef]

46. Masteller, C.C.; Finnegan, N.J.; Turowski, J.M.; Yager, E.M.; Rickenmann, D. History-dependent threshold for motion revealed by continuous bedload transport measurements in a steep mountain stream. Geophys. Res. Lett. 2019, 46, 2583-2591. [CrossRef]

47. Ferguson, R.I.; Bloomer, D.J.; Hoey, T.B.; Werritty, A. Mobility of river tracer pebbles over different timescales. Water Resour. Res. 2002, 38, 1045. [CrossRef]

48. Ballio, F.; Pokrajac, D.; Radice, A.; Hosseini Sadabadi, S.A. Lagrangian and Eulerian description of bedload transport. J. Geophys. Res. Earth Surf. 2018, 123, 384-408. [CrossRef]

49. Klösch, M.; Habersack, H. Deriving formulas from an unsteady virtual velocity of bedload tracers. Earth Surf. Process. Landf. 2018, 43, 1529-1541.

50. Parker, G. Tracer stones moving as bedload in gravel-bed streams. 1D Sediment Transport Morphodynamics with Applications to Rivers and Turbidity Currents. Ebook. 2004. Available online: http://hydrolab.illinois.edu/ people/parkerg/morphodynamics_e-book.htm.

51. Fernandez Luque, R.; Van Beek, R. Erosion and Transport of Bed-Load Sediment. J. Hydraul. Res. 1976, 14, 127-144. [CrossRef]

52. Laronne, J.B.; Outhet, D.N.; Duckham, J.L.; Mc Cabe, T.J. Determining event bedload volumes for evaluation of potential degradation site due to gravel extraction N.S.W., Australia. In Erosion and Sediment Transport Monitoring Programmes in River Basins, Proceedings of the Oslo Symposium, N.S.W., Australia, 24-28 August 1992; No. 210; IAHS Publication: Wallingford, UK, 1992; pp. 87-94.

53. Martin, Y.; Church, M. Bed-material transport estimated from channel surveys: Vedder River, British Columbia. Earth Surf. Process. Landf. 1995, 20, 347-361. [CrossRef]

54. Haschenburger, J.K.; Church, M. Bed material transport estimated from the virtual velocity of sediment. Earth Surf. Process. Landf. 1998, 23, 791-808. [CrossRef]

55. Liébault, F.; Laronne, J.B. Factors affecting the evaluation of bedload transport in gravel-bed rivers using scour chains and painted tracers: The case of the Esconavette Torrent. Geodin. Acta 2008, 21, 23-34.

56. Vázquez-Tarrío, D. Transporte de Sedimentos Como Carga de Fondo en la Cuenca del Río Narcea (Vertiente Norte de la Cordillera Cantábrica). Ph.D. Thesis, University of Oviedo, Oviedo, Spain, 2013.

57. Vázquez-Tarrío, D.; Menéndez-Duarte, R. Bedload transport rates for coarse-bed streams in an Atlantic region (Narcea River, NW Iberian Peninsula). Geomorphology 2014, 217, 1-14.

58. Vericat, D.; Wheaton, J.M.; Brasington, J. Revisiting the morphological approach: Opportunities and challenges with repeat high-resolution topography. In Gravel-Bed Rivers. Processes and Disasters; Tsutsumi, D., Laronne, J.B., Eds.; Wiley-Blackwell: Chichester, UK, 2017; pp. 121-158.

59. Gomez, B.; Church, M. An assessment of bedload sediment transport formulae for gravel-bed rivers. Water Resour. Res. 1989, 25, 1161-1186. [CrossRef]

60. Pitlick, J.; Cui, Y.; Wilcock, P. Manual for Computing Bedload Transport Using BAGS; USDA, Forest Service, Rocky Mountain Research Station: Fort Collins, CO, USA, 2009.

61. Vázquez-Tarrío, D.; Menéndez-Duarte, R. Assessment of bedload equations using data obtained with tracers in two coarse-bed mountain streams (Narcea River basin, NW Spain). Geomorphology 2015, 238, 78-93.

62. Eaton, B.; Church, M. A rational sediment transport scaling relation based on dimensionless stream power. Earth Surf. Process. Landf. 2011, 36, 901-910. [CrossRef]

63. Church, M.; Hassan, M.A. Size and distance of travel of unconstrained clasts on a streambed. Water Resour. Res. 1992, 28, 299-303. [CrossRef]

64. Hassan, M.A.; Church, M. The movement of individual grains on the streambed. In Dynamics of Gravel Bed Rivers; Bill, P., Hey, C.R., Thorne, C.R., Tacconi, P., Eds.; John Wiley \& Sons: Chichester, UK, 1992.

65. DeVries, P. Bedload Layer Thickness and Disturbance Depth in Gravel Bed Streams. J. Hydraul. Eng. 2002, 128, 983-991. [CrossRef]

66. Recking, A. Simple method for calculating reach-averaged bed-load transport. J. Hydraul. Eng. 2013, 139, 70-75. [CrossRef] 
67. McKenzie, L.G.; Eaton, B.C.; Church, M. Breaking from the average: Why large grains matter in gravel-bed streams. Earth Surf. Process. Landf. 2018, 43, 3190-3196. [CrossRef]

68. Haschenburger, J.K. A Probability model of scour and fill depths in gravel-bed channels. Water Resour. Res. 1999, 35, 2857-2869. [CrossRef]

69. Montgomery, D.R.; Buffington, J.M. Channel-reach morphology in mountain drainage basins. Geol. Soc. Am. Bull. 1997, 109, 596-611. [CrossRef]

70. Papangelakis, E.; Hassan, M. The role of channel morphology on the mobility and dispersion of bed sediment in a small gravel-bed stream. Earth Surf. Process. Landf. 2016, 41, 2191-2206. [CrossRef]

71. Gintz, D.; Hassan, M.A.; Schmidt, K.H. Frequency and magnitude of bedload transport in a mountain river. Earth Surf. Process. Landf. 1996, 21, 433-445. [CrossRef]

72. Bradley, D.N.; Tucker, G.E. Measuring gravel transport and dispersion in a mountain river using passive radio tracers. Earth Surf. Process. Landf. 2012, 37, 1034-1045. [CrossRef]

73. Liébault, F.; Bellot, H.; Chapuis, M.; Klotz, S.; Deschàtres, M. Bedload tracing in a high-sediment-load mountain stream. Earth Surf. Process. Landf. 2012, 37, 385-399.

74. Dell'Agnese, A.; Brardinoni, F.; Toro, M.; Mao, L.; Engel, M.; Comiti, F. Bedload transport in a formerly glaciated mountain catchment constrained by particle tracking. Earth Surface Dynamics 2015, 3, 527-542.

75. Miller, D.M. Reducing transformation bias in curve fitting. Am. Stat. 1984, 38, 124-126.

76. James, G.; Witten, D.; Hastie, T.; Tibshirani, R. An Introduction to Statistical Learning: With Applications in R; Springer Publishing Company, Incorporated: Berlin/Heidelberg, Germany, 2014.

77. Lindeman, R.H.; Merenda, P.F.; Gold, R.Z. Introduction to Bivariate and Multivariate Analysis; Scott Foresman \& Co: Glenview, IL, USA, 1980.

78. Quenouille, M.H. Problems in Plane Sampling. Ann. Math. Stat. 1949, 20, 355-375. [CrossRef]

79. Tukey, J.W. Bias and confidence in not quite large samples. Ann. Math. Stat. 1958, $29,614$.

80. Phillips, C.B.; Hill, K.M.; Paola, C.; Singer, M.B.; Jerolmack, D.J. Effect of flood hydrograph duration, magnitude, and shape on bedload transport dynamics. Geophys. Res. Lett. 2018, 45, 8264-8271.

81. Francalanci, S.; Solari, L.; Toffolon, M.; Parker, G. Do alternate bars affect sediment transport and flow resistance in gravel-bed rivers? Earth Surf. Process. Landf. 2012, 37, 866-875. [CrossRef]

82. Recking, A.; Piton, G.; Vázquez-Tarrío, D.; Parker, G. Quantifying the morphological print of bedload transport. Earth Surf. Process. Landf. 2016, 41, 809-822. [CrossRef]

83. Kasprak, A.; Wheaton, J.M.; Ashmore, P.E.; Hensleigh, J.W.; Peirce, S. The relationship between particle travel distance and channel morphology: Results from physical models of braided rivers. J. Geophys. Res. Earth Surf. 2015, 120, 55-74. [CrossRef]

84. Schmidt, K.; Ergenzinger, P. Bedload entrainment, travel lengths, step lengths, rest periods-Studied with passive (iron, magnetic) and active (radio) tracer techniques. Earth Surf. Process. Landf. 1992, 17, 147-165. [CrossRef]

85. Sawada, T.; Ashida, K.; Takahashi, T. Relationship between channel pattern and sediment transport in a steep gravel-bed river. Zeitschrift für Geomorphologie Suppl. 1983, 16, 55-66.

86. Lamarre, H.; Roy, A.G. A field experiment on the development of sedimentary structures in a gravel-bed river. Earth Surf. Process. Landf. 2008, 33, 1064-1081. [CrossRef]

87. Klingeman, P.C.; Emmett, W.W. Gravel bedload transport processes. In Gravel Bed Rivers: Fluvial Processes, Engineering and Management; Hey, R.D., Bathurst, J.C., Thorne, C.R., Eds.; Wiley: Chichester, UK, 1982; pp. 141-169.

88. Reid, I.; Frostick, L.E. Particle interaction and its effect on the thresholds of initial and final bedload motion in coarse alluvial channels. In Sedimentology of Gravels and Conglomerates; Memoir 10; Canadian Society of Petroleum Geologists: Calgary, AB, Canada, 1984; pp. 61-68.

89. Turowski, J.M.; Badoux, A.; Rickenmann, D. Start and end of bedload transport in gravel-bed streams. Geophys. Res. Lett. 2011, 38. [CrossRef]

90. Piton, G.; Recking, A. The concept of travelling bedload and its consequences for bedload computation in mountain streams. Earth Surf. Process. Landf. 2017, 42, 1505-1519. [CrossRef]

91. Piton, G.; Vázquez-Tarrío, D.; Recking, A. Can bed-load help to validate hydrology studies in mountainous catchment? The case study of the Roize (Voreppe-FR). E3S Web Conf. 2016, 7, 04020. [CrossRef]

92. Hassan, M.A.; Church, M. Vertical mixing of coarse particles in gravel bed rivers: A kinematic model. Water Resour. Res. 1994, 30, 1173-1186. [CrossRef] 
93. Ferguson, R.I.; Wathen, S.J. Tracer-pebble movement along a concave river profile: Virtual velocity in relation to grain size and shear stress. Water Resour. Res. 1998, 34, 2031-2038. [CrossRef]

94. Ferguson, R.; Hoey, T. Long-term slowdown of river tracer pebbles: Generic models and implications for interpreting short-term tracer studies. Water Resour. Res. 2002, 38, 1142. [CrossRef]

(C) 2019 by the authors. Licensee MDPI, Basel, Switzerland. This article is an open access article distributed under the terms and conditions of the Creative Commons Attribution (CC BY) license (http://creativecommons.org/licenses/by/4.0/). 